\title{
Efek Fortifikasi Asam Folat pada Beras Premiks Lokal terhadap Konsentrasi dan Hasil Belajar pada Santri
}

\section{Effect of Folic Acid Fortification on Local Premix Rice to Concentration and Student Learning Outcomes}

\author{
Aminuddin Syam ${ }^{1 *}$, Nurpudji Astuti Taslim², Budu², Nurhaedar Jafar'1, Muhammad \\ Jufri $^{3}$, Ismi Nurwaqiah Ibnu ${ }^{1}$, Andi Imam Arundhana ${ }^{1}$, Abdul Razak Thaha ${ }^{1}$ \\ ${ }^{1}$ Program Studi Ilmu Gizi, Fakultas Kesehatan Masyarakat, Universitas Hasanuddin \\ ${ }^{2}$ Program Studi Pendidikan Dokter, Fakultas Kedokteran, Universitas Hasanuddin \\ ${ }^{3}$ Program Studi Psikologi, Fakultas Psikologi Universitas Negeri Makassar \\ (*amin.gzuh@gmail.com)
}

\begin{abstract}
ABSTRAK
Kurangnya asupan zat besi dan asupan asam folat dapat menyebabkan kurangnya konsentrasi dan prestasi siswa. Tujuan penelitian ini menjelaskan pengaruh pemberian beras fortifikasi asam folat terhadap konsentrasi dan hasil belajar. Desain penelitian adalah eksperimen menggunakan rancangan Double Blind Randomized Control Trial. Populasi semua siswa pada pesantren Annihaya sebanyak 603 orang. Sampel adalah santri putra yang berumur 12-15 tahun sebanyak 80 orang. Sampel terdiri 4 kelompok yaitu kelompok yang diberikan beras fortifikasi (anemia dan non anemia) dan kelompok yang diberikan beras non-fortifikasi (anemia dan non anemia). Hasil penelitian menunjukkan penurunan skor konsentrasi terbesar pada kelompok intervensi yakni $-2,75$, sedangkan pada kontrol mengalami penurunan sebesar -1,65 dan tidak ada perbedaan signifikan baik dalam kelompok maupun perbedaan antara kelompok intervesi dan kontrol dengan nilai $p>0,05$. Kenaikan skor hasil belajar pada kelompok intervensi yakni sebesar 0,11 sedangkan pada kontrol mengalami penurunan sebesar -0,44. Terdapat perbedaan signifikan pada kelompok intervensi sebelum dan sesudah intervensi. Namun, secara statistik tidak ada perbedaan skor hasil belajar kelompok intervensi dan kontrol $(p>0,05)$. Kesimpulan bahwa konsentrasi santri mengalami penurunan pada semua kelompok setelah intervensi dan penurunan terbesar pada kelompok yang diberikan beras fortifikasi. Hasil belajar mengalami kenaikan pada semua kelompok setelah intervensi dan kenaikan terbesar terjadi pada kelompok anemia yang diberikan beras fortifikasi. Kata Kunci : Fortifikasi, asam folat, hasil belajar
\end{abstract}

\section{ABSTRACT}

Deficiency of iron intake and folic acid intake can cause a shortage of concentration and student achievement. The purpose of this study explains the effect of giving fortified rice with folic acid on concentration and Student learning outcome. This study is an experimental using the Double-Blind Randomized Control Trial Design. The population is students in the Annihaya boarding school is 603 people. The sample is 80 male students of aged 12-15 years. The sample was divided into four groups, namely groups given fortification rice (anemia and non-anemia) and groups given non-fortification rice (anemia and non-anemia). The results showed that the greatest decrease in concentration scores in the intervention group was -2,75, while in the control group, it decreased by -1,65 and there was no significant difference either in the group or the difference group with $p$ value $>0,05$. The increase in student learning outcomes in the intervention group was 0,11 while the control group had decreased by -0,44. The results show that there were significant differences in the intervention group before and after the intervention. But statistical tests showed there were no differences in student learning outcomes scores between the intervention group and the control group ( $p>0,05)$. The conclusion is that the concentration of students decreased in all groups after the intervention and the greatest decrease occurred in the group given non-anemic fortified rice. Student learning outcomes increased in all groups after the intervention and the largest increase occurred in the anemic group who were given fortified rice. Keywords : Fortification, folic acid, student learning outcome

Copyright (C) 2019 by author. This is an open access article under the CC BY-NC-SA license (https://creativecommons.org/licenses/by-nc-sa/4.0/).

DOI : http://dx.doi.org/10.30597/mkmi.v15i4.7621 


\section{PENDAHULUAN}

Kelompok remaja termasuk kelompok yang rentan mengalami masalah gizi karena pada periode ini terjadi growth spurt atau pertumbuhan dan perkembangan yang cepat sehingga kebutuhan gizi juga meningkat pesat. Adanya growth spurt ini diikuti dengan perubahan hormonal, kognitif, dan emosional membuat periode remaja ini salah satu fase yang rentan terhadap masalah kesehatan. ${ }^{1} \mathrm{Se}-$ cara tidak langsung, beberapa faktor yang memengaruhi masalah kesehatan dan gizi pada remaja adalah tingkat pengetahuan, praktik pola makan yang tidak sesuai dengan prinsip gizi seimbang, pengaruh pergaulan, sanitasi yang buruk, dan perkembangan teknologi. ${ }^{2}$

Anemia pada anak sekolah dikenal menjadi masalah kesehatan masyarakat yang secara global mencapai $25,4 \%$ dan lebih dari $50 \%$ mengalami anemia defisiensi zat besi (iron deficiency anemia). ${ }^{3}$ Menurut WHO di Asia Tenggara bahwa tingkat Iron Deficiency Anemia (IDA) pada remaja putri mencapai $15-40 \%$. Hasil Riset Kesehatan Dasar tahun 2013 menunjukkan prevalensi anemia anak sekolah meningkat secara ekstrim menjadi $26,4 \%$ dan lebih dari setengahnya mengalami IDA. ${ }^{4}$ Dampak dari masalah anemia dan IDA sangat luas, seperti memengaruhi imunitas, kecepatan pertumbuhan, kognitif anak hingga perkembangan otak yang memengaruhi fungsi neurologis dan konsentrasi dan performa berlajar. ${ }^{5,6,7}$

Perkembangan otak dimulai pada saat masa prenatal dan berlangsung hingga usia sekolah. Dimulai dengan membentuk sel-sel otak, diikuti migrasi dan diferensiasi sel otak, dan perkembangan sinaptik yang memungkinkan sel berkomunikasi satu sama lain sehingga fungsi otak dapat bekerja maksimal. Asam folat dan zink termasuk zat gizi mikro yang berperan terhadap mekanisme ini, baik secara langsung maupun tidak langsung. ${ }^{8}$

Food and Agriculture Organization (FAO) telah menetapkan 4 strategi untuk menyelesaikan masalah defisiensi zat gizi mikro, diantaranya adalah 1) diversifikasi pangan, 2) fortifikasi pangan, 3) suplementasi dengan vitamin dan mineral, serta 4) pengukuran kesehatan masyarakat global dan kontrol penyakit. ${ }^{10}$ Fortifikasi pangan salah satu strategi yang paling baik karena memiliki nilai ekonomis dengan tingkat kepatuhan yang lebih tinggi, sehingga cara ini lebih efektif dalam menurunkan masalah defisiensi zat gizi termasuk anemia. Beberapa negara telah melakukan upaya fortifikasi pada beberapa produk seperti tepung, minyak, kecap, mie, maupun beras. ${ }^{11-13}$

Salah satu metode fortifikasi beras adalah dengan metode premix kernel. Premix kernel merupakan ekstrudat menyerupai bulir beras yang telah ditambahkan zat besi (feri pirofosfat), dapat dibuat dengan dua cara yaitu cold-extrusion dan hot-extrusion. Seiring dengan berkembangnya teknologi di Indonesia, pada penelitian ini proses premix dilakukan di dalam negeri menggunakan bahan nutrisi lokal di Indonesia, sehingga disebut premix lokal. Fortifikasi beras di Indonesia dapat menjadi strategis yang prospektif (baik) dalam mengatasi masalah kekurangan gizi mikro oleh karena beras merupakan komoditi utama yang hampir seluruh penduduk Indonesia mengonsumsinya. Berdasarkan data Susenas tahun 2013-2017 (Triwulan 1), bahwa rata-rata konsumsi beras per hari penduduk Indonesia mencapai 263,9 g/orang, dan tidak jauh berbeda antara konsumsi di perkotaan $(253,3 \mathrm{~g} /$ orang/hari) dan pedesaan $\left(274,4 \mathrm{~g} /\right.$ orang/hari). ${ }^{14}$ Saat ini beras yang ada hanya mampu memberikan sumbangsih kalori tapi rendah zat gizi mikro seperti asam folat, vitamin B1, niasin, zat besi, dan zink. Sehingga melalui fortifikasi pada beras dapat memberikan asupan zat gizi mikro ketika dikonsumsi. Menurut studi yang dilakukan Radhika, bahwa tidak ada perbedaan daya terima antara beras fortifikasi dan non fortifikasi. ${ }^{15}$ Selain itu, berdasarkan estimasi biaya oleh beberapa ahli bahwa selain zat besi, yang selama ini dikenal cost effective dalam program fortifikasi, asam folat dan zink juga memiliki cost benefit dalam program fortifikasi. ${ }^{16}$

Sebuah studi baru, remaja yang mengonsumsi dalam jumlah tinggi folat dalam diet mereka dapat meningkatkan pencapaian akademis. ${ }^{17}$ Penelitian lain menunjukkan bahwa asupan folat yang lebih tinggi berhubungan positif dengan prestasi akademik pada anak sekolah usia 15 tahun, diukur melalui nilai sekolah di semester akhir. ${ }^{18}$ Asupan mikronutrien yang cukup dapat mencegah terjadinya gangguan pada mielinasi dan berdampak signifikan pada fungsi sistem saraf pusat. Hambatan mielinasi dari otak anak dapat menyebabkan keterlambatan kemampuan kognitif termasuk konsentrasi dan memori, serta atrofi otak. ${ }^{9} 19$ 
Asupan zat gizi mikro yang mendukung kognitif, konsentrasi dan prestasi akademik dapat diperoleh melalui beras yang difortifikasi dengan multimikronutrien. Meskipun mekanisme ini tidak dapat dijelaskan secara rinci akan tetapi tampaknya peran zat gizi tersebut pada neurogenesis, migrasi neuronal, dan synaptogenesis yang membangun neurotransmisi sehingga meningkatkan kemampuan otak. ${ }^{17}$ Meskipun telah banyak studi yang memperlihatkan pengaruh asam folat terhadap perkembangan otak dan fungsinya, tetapi masih terbatas penelitian pada hewan. Oleh karena itu, penelitian pada manusia perlu dilakukan untuk melihat apakah efek beras fortifikasi dengan premix local khususnya kandungan asam folat yang adekuat dapat meningkatkan pertumbuhan dan perkembangan otak (peningkatan konsentrasi dan hasil belajar).

\section{BAHAN DAN METODE}

Penelitian ini adalah bagian dari penelitian induk yaitu: "Studi Efikasi Dampak Pemberian Beras yang Difortifikasi dengan Premiks Lokal terhadap Konsentrasi Hb, Ferritin, Zink, dan Prevalensi Anemia pada Santri di Kabupaten Karawang". Rancangan penelitian dalam studi efikasi ini adalah Double Blind Randomized Control Trial atau $D B-R C T$. Responden dan peneliti tidak mengetahui apakah yang dikonsumsi adalah beras fortifikasi atau bukan, hal ini untuk mengurangi bias dalam penelitian.
Populasi dalam penelitian ini adalah semua siswa pada pesantren Annihaya yang jumlahnya 603 orang. Besar sampel dihitung dengan menggunakan formula perhitungan sampel untuk menguji hipotesis perbedaaan mean dalam suatu studi eksperimen (intervensi). ${ }^{20}$ Kriteria Sampel dalam penelitian ini terdiri dari kriteria inklusi yaitu jenis kelamin laki-laki, umur 12-15 tahun, memiliki konsentrasi $\mathrm{Hb} \geq 8 \mathrm{mg} \%$ sampai $\leq 13 \mathrm{mg} \%$, bersedia menjadi sampel dengan menandatangani informed concent. Sedangkan kriteria eksklusi penelitian ini yaitu memiliki riwayat penyakit infeksi seperti TBC, malaria, talasemia dan memiliki riwayat penyakit non infeksi seperti penyakit jantung, DM, kanker, ginjal kronik, dan menderita pendarahan akut dan kronik. Sampel kemudian dibagi kedalam empat kelompok responden yaitu kelompok I anemia yang mendapat fortifikasi, kelompok II anemia non fortifikasi, kelompok III non anemia fortifikasi dan kelompok IV non anemia non fortifikasi. Pelakuan kedua kelompok tersebut dilakukan selama 6 bulan.

Tahap baseline seluruh santri ikut pada semua variabel, namun selama intervensi responden pada varibel biokimia dan status gizi mengalami drop out sebanyak 36 orang sedangkan untuk variabel hasil belajar tersisa 92 orang dari 160 orang responden dan variabel konsentrasi 112 responden. Sedangkan pada tahap endline 36 orang drop out pada variabel biokimia dan status gizi. Khusus pada variabel hasil belajar, 8 orang drop

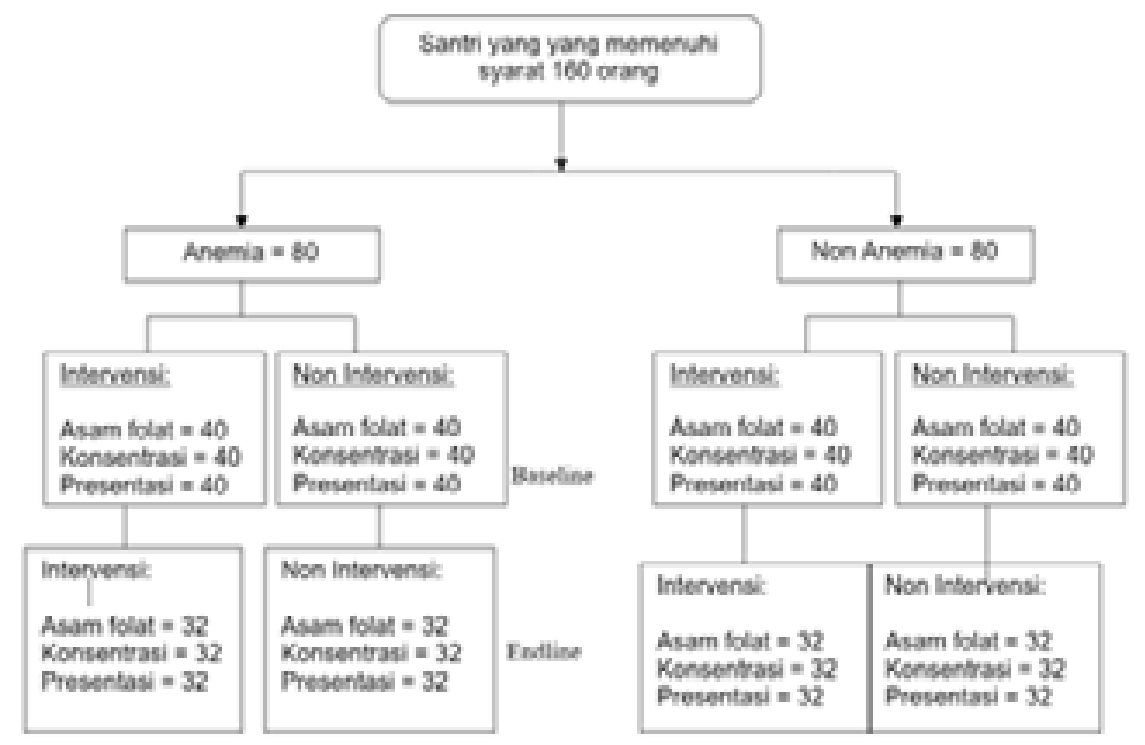

Gambar 1. Alur Rekrutmen Sampel dan Follow up 
out karena termasuk santri salafi yang tidak punya nilai ijazah sebagai patokan untuk nilai baseline. Variabel lain faktor penyebab drop out diantaranya disebabkan karena tidak bersedia lagi menjadi sampel; pendarahan berulang; diare berulang; tidak mengisi kuisioner secara lengkap; pindah sekolah; tidak mengonsumsi makanan di pesantren lebih dari 3 hari dan mengundurkan diri. Gambaran mengenai alur studi penelitian tersaji pada (gambar 1).

Instrumen yang digunakan dalam penelitian ini ialah formulir data identitas murid untuk skrining dan pemilihan sampel, formulir kesediaan menjadi responden (informed concent), formulir FFQ Semi kuantitatif, timbangan digital Merek SECA dengan akurasi $0,1 \mathrm{~kg}$, kuisioner data karakteristik sampel, kuisioner konsentrasi, timbangan makanan merek TANITA 0,1 gram, peralatan makan, kompor dan alat masak, alat kelengkapan laboratorium untuk mengukur serum asam folat dalam darah. Alat, program dan dokumen manajemen data.

Uji statistik dalam penelitian ini adalah analisis bivariat, dilakukan untuk menguji perbedaan kadar serum asam folat sebelum dan setelah intervensi dilakukan uji beda untuk analisis adalah uji Paired Samples T-Test begitupula untuk variabel konsentrasi dan hasil belajar. Karakteristik responden, asupan zat gizi (FFQ Semi kuantitatif), kadar serum asam folat awal, kadar serum asam folat akhir, perubahan kadar serum asam folat, dilakukan uji One Way Anova, analisis dengan General Linier Model (GLM) dilakukan untuk menguji perbedaan perubahan kadar serum asam folat antara kelompok dengan memasukkan beberapa kovariat.

\section{HASIL}

Berdasarkan tabel 1, menggambarkan bahwa karakteristik sampel penelitian ini adalah lebih separuh sampel masih kelas VII yakni 53,75\% sedangkan kelas IX hanya $13,75 \%$. Suku bangsa orang tua santri baik ayah maupun ibu paling banyak suku Sunda yakni masing-masing $65 \%$ dan $73,1 \%$. Pekerjaan orang tua santri, untuk ayah sebanyak $43,1 \%$ berprofesi wiraswasta, sedangkan ibu santri paling banyak berprofesi sebagai ibu rumah tangga yakni sebanyak $71,8 \%$. Sedangkan pendidikan orang tua santri yang paling banyak tamat SLTA masing-masing, ayah $28,75 \%$ dan ibu $26,25 \%$.

Tabel 2 menunjukkan bahwa kadar asam folat terjadi kenaikan pada kelompok I (Kelompok Intervensi anemia) maupun kelompok II (Kelompok kontrol anemia). Kenaikan terbesar terjadi pada kelompok II yaitu 1,91. Selain itu terjadi penurunan skor konsentrasi santri sebelum dan sesudah intervensi pada semua kelompok. Penurunan terbesar pada kelompok III yakni kelompok intervensi non anemia sebesar $-3,85$. Sedangkan penurunan terkecil pada kelompok II kelompok kontrol anemia sebesar -0,59. Hasil uji

Tabel 1. Distribusi Karakteristik Sampel

\begin{tabular}{|c|c|c|c|c|}
\hline \multirow{2}{*}{ Karakteristik } & \multicolumn{2}{|c|}{ Anemia } & \multicolumn{2}{|c|}{ Non Anemia } \\
\hline & Kelompok I & Kelompok II & Kelompok III & Kelompok IV \\
\hline \multicolumn{5}{|l|}{ Kelas, n (\%) } \\
\hline Kelas $1, \mathrm{n}=86(53,75)$ & $19(22,1)$ & $24(27,9)$ & $19(22,1)$ & $24(27,9)$ \\
\hline Kelas $2, \mathrm{n}=52(32,5)$ & $26(30,8)$ & $12(23,1)$ & $14(26,9)$ & $10(19,2)$ \\
\hline Kelas $3, \mathrm{n}=22(13,75)$ & $5(22,7)$ & $4(18,2)$ & $7(31,8)$ & $6(27,3)$ \\
\hline \multicolumn{5}{|l|}{ Suku Orang Tua, n (\%) } \\
\hline Ayah, Sunda n=104(65) & $22(22,1)$ & $27(26,0)$ & $27(26,0)$ & $28(26,9)$ \\
\hline Ibu, Sunda $n=117(73,1)$ & $29(30,8)$ & $29(24,8)$ & $29(24,8)$ & $30(25,6)$ \\
\hline \multicolumn{5}{|l|}{ Pekerjaan Orang Tua, n (\%) } \\
\hline Ayah, Wiraswastan $=69(43,1)$ & $24(34,8)$ & $16(23,2)$ & $18(26,1)$ & $11(15,9)$ \\
\hline Ibu, IRT n=115 $(71,8)$ & $29(25,2)$ & $29(25,2)$ & $29(25,2)$ & $28(24,3)$ \\
\hline \multicolumn{5}{|l|}{ Pendidikan Orang Tua, n (\%) } \\
\hline Ayah, SLTA n=46(28,75) & $14(30,4)$ & $6(13,0)$ & $13(28,3)$ & $13(28,3)$ \\
\hline Ibu, SLTA n=42(26,25) & $16(38,1)$ & $8(19,0)$ & $12(28,6)$ & $6(14,3)$ \\
\hline
\end{tabular}

Sumber: Data Primer, 2015 
Tabel 2. Distribusi Serum Asam Folat, Konsentrasi serta Prestasi Belajar Responden Sebelum dan Sesudah Intervensi

\begin{tabular}{lcccc}
\hline \multicolumn{1}{c}{ Kelompok } & $\mathbf{n}$ & $\begin{array}{c}\text { Baseline } \\
\text { Mean } \mathbf{( 9 5 \%} \mathbf{C I})\end{array}$ & $\begin{array}{c}\text { Endline } \\
\text { Mean } \mathbf{( 9 5 \%} \mathbf{C I})\end{array}$ & $\begin{array}{c}\text { Perbedaan } \\
\text { Mean }(\mathbf{9 5 \%} \text { CI) } \mathbf{p 1 ~ p 2}\end{array}$ \\
\hline Asam folatdL & & & & \\
$\quad$ Kelompok I & 32 & $18.18(16.80,19.57)$ & $19.92(18.22,21.62)$ & $1.74(0.27,3.21)^{1}$ \\
$\quad$ Kelompok II & 32 & $17.89(16.19,19.60)$ & $19.81(17.81,21.81)$ & $1.91(-0.40,4.24)$ \\
Konsentrasi & & & & \\
$\quad$ Kelompok I & 31 & $113.39(109.03,117.75)$ & $111.55(107.92,115.17)$ & $-1.84(-6.21,2.22)^{1}$ \\
Kelompok II & 32 & $112.75(109.39,116.11)$ & $112.16(109.66,114.65)$ & $-0.59(-3.29,2.44)^{1}$ \\
Kelompok III & 26 & $120.15(117.03,123.28)$ & $116.31(113.14,119.47)$ & $-3.85(-6.94,-0.32)^{1}$ \\
Kelompok IV & 23 & $116.04(112.14,119.95)$ & $112.91(109.12,116.71)$ & $-3.13(-7.17,0.78)^{1}$ \\
Prestasi belajar & & & & \\
Kelompok I & 31 & $3,06(3.02,3.10)$ & $3,18(3.16,3.21)$ & $0,12(0.08,0.17)^{1}$ \\
Kelompok II & 32 & $3,08(3.02,3.14)$ & $3,19(3.15,3.23)$ & $0,11(0.03,0.19)^{1}$ \\
Kelompok III & 26 & $3,14(3.05,3.24)$ & $3,19(3.14,3.23)$ & $0,04(-0.05,0.14)$ \\
Kelompok IV & 9 & $3,06(2.97,3.15)$ & $3,16(3.08,3.24)$ & $0,10(0.03,0.16)^{1}$ \\
\hline
\end{tabular}

Sumber : Data Primer, 2015

${ }^{1}$ uji t berpasangan; ${ }^{a} u j i$ t independen

${ }^{1}$ signifikan $(\mathrm{p}<0,05)$

Tabel 3. Distribusi Skor Konsentrasi, Skor Hasil Belajar, dan Status Gizi Berdasarkan Kelompok Intervensi

\begin{tabular}{lcccc}
\hline \multicolumn{1}{c}{ Kelompok } & $\mathbf{n}$ & $\begin{array}{c}\text { Baseline } \\
\text { Mean }(\mathbf{9 5 \%} \text { CI) }\end{array}$ & $\begin{array}{c}\text { Endline } \\
\text { Mean (95\% CI) }\end{array}$ & $\begin{array}{c}\text { Perbedaan } \\
\text { Mean (95\% CI) }\end{array}$ \\
\hline $\begin{array}{l}\text { Konsentrasi } \\
\quad \text { Intervensi }(1 \& \text { 3) }\end{array}$ & 57 & $116.47(113.64,119.31)$ & $113.72(111.27,116.17)$ & $-2.75(-4.74,2.54)$ \\
$\quad$ Non-intervensi (2\&4) & 55 & $113.13(111.62,116.63)$ & $112.47(110.40,114.55)$ & $-1.65(-4.74,2.54)$ \\
Hasil Belajar & & & & \\
$\quad$ Intervensi (1 \& 3) & 45 & $3.11(3.07,3.16)$ & $3.22(3.19,3.24)$ & $0.11(0.06,0.05)^{1}$ \\
$\quad$ Non-intervensi (2\&4) & 47 & $3.66(3.47,3.86)$ & $3.22(3.19,3.24)$ & $-0.44(-1.65,0.75)^{1}$ \\
\hline
\end{tabular}

Sumber : Data Primer, 2015

${ }^{1} \mathrm{uji} \mathrm{t}$ berpasangan; ${ }^{\mathrm{a} u j i} \mathrm{t}$ independen

t berpasangan menunjukkan bahwa terdapat perbedaan secara signifikan skor konsentrasi sebelum sesudah pada masing-masing kelompok dengan nilai $p<0,05$, tetapi hasil uji $\mathrm{t}$ independen tidak menujukkan adanya perbedaan antara kelompok sebelum dan sesudah intervensi.

Hasil penelitian juga menunjukkan bahwa terjadi peningkatan skor prestasi belajar santri sebelum dan sesudah intervensi pada semua kelompok. Kenaikan terbesar pada kelompok I yakni kelompok intervensi anemia sebesar 0,12 , kemudian disusul oleh kelompok II yakni anemia non intervensi dengan kenaikan sebesar 0,11. Sedangkan kelompok III mengalami kenaikan terkecil yaitu 0,05 sedangkan kelompok IV kenaikannya sebesar 0,1 . Hasil uji t berpasangan menunjukkan bahwa terdapat perbedaan secara signifikan skor hasil belajar sebelum sesudah pada masing-masing kelompok I, II dan IV dengan nilai $p<0,05$, tetapi hasil uji $t$ independen tidak menujukkan adanya perbedaan antar kelompok intervensi dan kelompok kontrol (Tabel 2).

Hasil penelitian menunjukkan bahwa terjadi penurunan skor konsentrasi santri baik pada kelompok intervensi maupun kontrol. Penurunan terbesar pada kelompok intervensi yakni $-2,75$ sedangkan pada kelompok kontrol mengalami penurunan sebesar $-1,65$. Hasil uji t berpasangan dan independen t-test menujukkan bahwa tidak ada perbedaan secara signifikan baik dalam kelompok maupun perbedaan antara kelompok intervesi dengan kelompok kontrol dengan nilai $p>0,05$ (Tabel 3). Penelitian ini menunjukkan bahwa terjadi kenaikan skor hasil belajar santri baik 
pada kelompok intervensi sedangkan pada kelompok kontrol terjadi penurunan. Kenaikan pada kelompok intervensi yakni sebesar 0,11 sedangkan pada kelompok kontrol mengalami penurunan sebesar -0,44. Hasil uji t berpasangan menujukkan bahwa terdapat berbedaan secara signifikan pada kelompok intervensi sebelum dan sesudah intervensi. Namun, hasil uji t independen menunjukkan bahwa tidak ada perbedaan secara signifikan skor hasil belajar antara kelompok intervensi dengan kelompok kontrol dengan nilai $\mathrm{p}>0,05$ (Tabel 3).

Berdasarkan hasil uji t independen menunjukkan bahwa diantara variabel pengganggu sesudah intervensi, hanya makanan penghambat yang memiliki nilai signifikan yakni $p=0,04$ sedangkan variabel pengganggu lainnya seperti zat pelancar $(p=0,86)$, uang jajan $(p=0,39)$, durasi diare $(p=0,18)$, frekuensi diare $(p=0,24)$, durasi ISPA $(p=1,00)$ dan frekuensi ISPA $(p=0,27)$ tidak ada perbedaan secara bermakna.

\section{PEMBAHASAN}

Bioavailabilitas asam folat sebagian besar diatur oleh tingkat absorpsi usus. Polyglutamyl folat, yang merupakan kebanyakan folat alami makanan, harus menjalani deconjugation enzimatik di usus kecil sebelum penyerapan. Reaksi ini dikatalisis terutama oleh hidrolase pteroylpolyglutamate terkait dengan membran brush border jejunum, dengan beberapa kontribusi oleh aktivitas hidrolase dari sekresi pankreas. Penyerapan folat monoglutamil terjadi melalui proses transport saturable dengan $\mathrm{pH}$ asam optimal dan mekanisme penyerapan, ternyata nonsaturable juga berfungsi ketika konsentrasi folat dalam isi usus melebihi $5-10 \mathrm{mmol} / \mathrm{L}$. Adanya keberadaan dua proses penyerapan, temuan mengenai folat bioavailabilitas pada tingkat dosis tertentu mungkin tidak dapat memprediksi bioavailabilitas pada asupan jauh lebih tinggi atau lebih rendah. $\mathrm{pH}$ optimum untuk transportasi folat adalah 5 , sedangkan $\mathrm{pH}$ optimum dari deconjugation enzimatik adalah 6-7. ${ }^{21}$

Hasil penelitian ini menunjukkan bahwa terjadi peningkatan secara bermakna perubahan asam folat setelah intervensi pada kelompok anemia yang diberikan beras fortifikasi, namun tidak bermakna pada kelompok II (kontrol) yakni kelompok anemia tanpa beras fortifikasi. Kadar asam folat pada kelompok intervensi meningkat secara bermakna $(p<0,05)$ dari $18,18(95 \%$ CI $16,80-19,57)$ pada saat sebelum intervensi dan mengalami peningkatan menjadi 19,92 (95\% CI 18,22-21,62) sesudah intervensi, yakni mengalami peningkatan sebesar 1,74 (95\% CI 0,27-3,21). Sedangkan pada kelompok kontrol, meskipun mengalami peningkatan sebesar 1,91 (95\% CI -0,40, 4,24) namun tidak bermakna secara signifikan dengan nilai $p>0,05$.

Penelitian ini sejalan dengan beberapa penelitian intervensi dengan asam folat sebelumnya, Jani, dkk melakukan penelitian untuk menentukan status folat dari populasi remaja dan untuk menunjukkan efek dari suplementasi asam folat pada subjek dengan status folat rendah. Anak laki-laki secara signifikan memiliki kadar folat lebih tinggi dalam serum dan eritrosit daripada anak perempuan. Suplementasi 400 mikrogram asam folat setiap hari selama 2 bulan mengakibatkan secara signifikan peningkatan folat serum, eritrosit folat, dan nilai-nilai hemoglobin dan penurunan rata-rata volume corpuscular. ${ }^{22}$ Temuan kekurangan kadar asam folat pada siswa memang cukup tinggi. Penelitian yang dilakukan di Indian pada remaja menunjukkan anak perempuan memiliki asupan folat yang sangat kurang daripada anak laki-laki. Temuan ini menjadi perhatian karena kekurangan folat dapat memiliki konsekuensi kesehatan yang merugikan (misalnya, penyakit kardiovaskular) untuk individu yang dapat dibawa ke masa dewasa. ${ }^{23}$

Hasil studi yang dilakukan Fei Ma, dkk tentang efek suplementasi asam folat terhadap fungsi kognitif pada lansia, menunjukkan setelah suplementasi selama 6 bulan, kadar serum folat secara signifikan lebih besar pada kelompok asam folat dibandingkan kelompok kontrol. Selain itu, hasil pengukuran kognitif menunjukkan kelompok intervensi memiliki rata-rata skor yang lebih baik daripada kelompok kontrol. Terdapat efek yang menguntungkan dari suplementasi folat jangka pendek pada fungsi kognitif. ${ }^{24}$ Hasil studi jangka panjang diet dikontrol dengan subjek manusia menunjukkan bahwa bioavailabilitas folat dalam diet yang beragam biasa tidak lebih dari $50 \%$ dibandingkan dengan asam folat dalam diet susu formula. $^{21}$

Beberapa bukti menunjukkan bioavailabilitas yang lebih tinggi dari penambahan asam folat 
dibandingkan folat alami dalam banyak makanan. Selain itu, folat ditambahkan ke berbagai makanan sereal gandum juga menggambarkan bioavailabilitas mirip dengan asam folat dalam larutan air dan folat dengan difortifikasi pada sarapan sereal telah terbukti efektif dalam meningkatkan status folat pada manusia. ${ }^{25}$ Fortifikasi asam folat pada beras (salah satu serealia) dapat menjadi salah satu solusi untuk meningkatkan asupan folat dengan bioavaliabilitas yang efektif. Selain itu, fortifikasi beras juga bisa menjangkau semua sasaran hingga pedesaan dan mudah diperoleh. Sehingga dapat dijadikan salah satu strategi intervensi yang baik diterapkan.

Skor konsentrasi responden mengalami penurunan, baik pada kelompok intervensi maupun kelompok kontrol. Penurunan skor konsentrasi terjadi pada kelompok intervensi yakni sebesar -2,75 (95\% CI -4,74, 2,54), sedangkan pada kelompok kontrol penurunannya -1,65 (95\% CI $-4,74-2,54)$. Kelompok intervensi, skor konsentrasi menurun dari 116,47 poin menjadi 113,72 poin. Sedangkan pada kelompok kontrol, skor konsentrasi menurun dari 113,13 poin menjadi 112,47 poin. Tidak ada perbedaan antara kelompok intervensi dengan kelompok kontrol terhadap pemberian beras fortifikasi yang mengandung asam folat dan zink.

Secara teoritis adanya penurunan konsentrasi pada kelompok intervensi dan kontrol mungkin disebabkan karena item pertanyaan tidak menjadi retensi atau penyimpanan pengetahuan (memory trace) pada kedua kelompok, karena biasanya yang disimpan adalah konsep-konsep, bukan informasi kata demi kata sehingga pertanyaan yang diberikan sesudah intervensi hanya menjadi ingatan jangka pendek yang berlangsung beberapa detik atau beberapa jam saja. Konsentrasi terkait dengan memori jangka pendek (short term memory) ialah penyimpanan sementara peristiwa atau item yang diterima dalam waktu sekejap, yakni kurang dari beberapa menit. Memori jangka pendek tidak parmanen, penyimpanannya akan terhapus dalam waktu pendek, kecuali kalau diupayakan secara khusus seperti mengulang-ulang. ${ }^{26}$

Menurunnya skor konsentrasi pada akhir penelitian ini membuktikan bahwa konsentrasi hanya terkait dengan memori jangka pendek. Masalah memori jangka pendek yang penting dalam kehidupan sehari-hari adalah memori kerja dengan mekanisme kerja yakni penggabungan antara fungsi memori yang dipantau oleh struktur yang berada di otak bagian pelipis (lobus temporale) dan fungsi eksekutif yang berada di otak bagian depan (lobus frontal).

Hasil penelitian yang dilakukan oleh Khodashenas, dkk menemukan terdapat perbedaan hasil tes kognitif siswa SD yang diberikan suplemen Zink dengan kelompok placebo $(p<0,05) .{ }^{27}$ Demikian pula hasil penelitian yang dilakukan oleh Robinson, yang meneliti tentang efek suplementasi besi dan zink pada anak-anak, menemukan bahwa semua anak yang mengalami defisiensi besi dan zink juga mengalami penurunan daya ingat dan konsentrasi. Setelah pemberian suplementasi terjadi peningkatan yang signifikan pada daya ingat dan konsentrasi. ${ }^{28}$

Hasil penelitian ini menggambarkan bahwa skor hasil belajar pada kedua kelompok mengalami peningkatan, yakni pada kelompok intervensi meningkat menjadi 0,10 (CI 95\% 0,17-0,03) sedangkan kelompok kontrol meningkat menjadi 0,11 (CI 95\% 0.19- 0.25). Hasil analisis memperlihatkan bahwa kedua kelompok bermakna secara signifikan sebelum dan setelah intervensi tetapi jika dibandingkan antara kelompok intervensi dengan kelompok kontrol tidak ada perbedaan bermakna antar kedua kelompok.

Peningkatan skor prestasi pada kedua kelompok disebabkan karena proses belajar merupakan bagian dari proses memori jangka panjang (long term memory). Pemberian informasi atau pelajaran secara berulang-ulang setiap hari belajar menyebabkan ingatan lebih lama bahkan menjadi bank memori yang parmanen. Proses belajar yang sifatnya berulang dan parmanen disebabkan karena terjadinya konsolidasi memori secara intensif. Proses konsolidasi memori mencakup; proses pemindahan (transfer) materi dari memori jangka pendek ke memori jangka panjang dan kemudian dilanjutkan dengan proses konsolidasi memori ke dalam penyimpanan (storage). ${ }^{29}$

Hasil penelitian Kooshki yang menemukan bahwa asam folat dan zink sangat penting bagi perkembangan otak. Asam folat mendukung metabolisme zat besi dan mencegah anemia. Kekurangan asam folat secara tidak langsung dapat memengaruhi perkembangan kognitif, konsentrasi, dan 
tingkat energi. ${ }^{17}$ Studi terbaru menyebutkan bahwa zat gizi asam folat dapat membuat anak lebih cerdas namun mekanismenya belum dapat dijelaskan secara rinci.

Hasil penelitian lain menunjukkan bahwa anak-anak yang ibunya mengonsumsi suplemen zat besi dan asam folat selama kehamilan memiliki tingkat intelektual yang lebih tinggi dan kemampuan motorik yang sangat baik selama tahun-tahun usia sekolah, serta keterampilan organisasi yang lebih baik. Besi dan asam folat memainkan peran penting dalam pertumbuhan dan perkembangan anak, utamanya pengembangan dini sistem saraf. Sel glia yang diperlukan untuk meelinisasi akson, dan mengalami pertumbuhan 10 kali lipat pada tahun pertama, terutama oligodendrosit. Pertumbuhan sel glia sangat bergantung pada zat besi. ${ }^{30}$

\section{KESIMPULAN DAN SARAN}

Kesimpulan dalam penelitian ini adalah terjadi peningkatan serum asam folat secara signifikan pada kelompok anemia yang mendapatkan beras fortifikasi, konsentrasi santri mengalami penurunan pada semua kelompok setelah intervensi. Penurunan terbesar terjadi pada kelompok yang diberikan beras fortifikasi yang non anemia, serta hasil belajar santri mengalami kenaikan pada semua kelompok setelah intervensi. Kenaikan terbesar terjadi pada kelompok anemia yang diberikan beras fortifikasi. Peneliti menyarankan untuk menilai konsentrasi perlu kuesioner yang lebih spesifik dan dapat mengukur komponen tertentu seperti kecerdasan intelektual atau kecerdasan emosional, hasil belajar yang dinilai perlu lebih spesifik dan fokus pada mata pelajaran tertentu, serta diperlukan sampel yang lebih besar dan memasukkan aspek sosial budaya masyarakat sebagai variabel penelitian.

\section{DAFTAR PUSTAKA}

1. CDPH. California Nutrition and Physical Activity Guidelines for Adolescents: Adolescent Nutrition. In: Maternal, Child and Adolescent Health Division, Center for Familiy Health, California Departement of Public Health. California Department of Public Health; 2013. pp 1-10.

2. Maziya N. Adolescent Nutritional Status and its Association with Village-Level Factors in
Tanzania; 2014.

3. WHO. Ambition and Action in Nutrition 2016-2015. Switzerland; 2017.

4. Kemenkes RI. Riset Kesehatan Dasar. Jakarta: Kementerian Kesehatan RI; 2013.

5. Subramaniam G, Girish M. Iron Deficiency Anemia in Children. Indian Journal of Pediatrics. 2015;82(6):558-564.

6. Guo XM, Liu H, Qian J. Daily Iron Supplementation on Cognitive Performance in Primary-School-Aged Children with and Without Anemia: A Meta-Analysis. International Journal Clinical and Experimental Medicine. 2015;8(9):16107-16111.

7. Iqbal K, Zafar T, Iqbal Z, Usman M, Bibi H, Afreen MS, et al. Effect of Iron Deficiency Anemia on Intellectual Performance of Primary School Children in Islamabad, Pakistan. Tropical Journal of Pharmaceutical Research. 2015;14(2):287-291.

8. Wang M. Iron Deficiency and Other Types of Anemia in Infants and Children. American Family Physician. 2016;93(4):270-278.

9. Prado EL, Dewey KG. Nutrition and Brain Development in Early Life. Nutrition Reviews. 2014;72(4):267-284.

10. Maroyi A. Not Just Minor Wild Edible Forest Products: Consumption of Pteridophytes in Sub-Saharan Africa. Journal of Ethnobiology and Ethnomedicine. 2014;10:1-9 .

11. Hettiarachchi M, Liyange' C, Hilmers DC, Abrams' SA. Efficacy of Rice Flour Fortification in Sri Lanka: A Pilot Study. Procedings of the Secound Academic Sessions; 2004.

12. Rebellato AP, Klein B, Wagner R, Azevedo Lima Pallone J. Fortification of Whole Wheat Flour with Different Iron Compounds: Effect on Quality Parameters and Stability. Journal of Food Science and Technology. 2018; 55(9):3575-3583.

13. Laillou A, Pfanner S, Chan T, Chea C, Mam $\mathrm{B}$, Sambath $\mathrm{P}$, et al. Beyond effectiveness the Adversities of Implementing a Fortification Program. A Case Study on the Quality of Iron Fortification of Fish and Soy Sauce in Cambodia. Nutrients. 2016;8(2):1-8.

14. BPS. Survei Sosial Ekonomi Nasional 2013. Jakarta: Badan Pusat Statistik: SUSENAS; 2014. 
15. Radhika MS, Nair KM, Hari Kumar R, Vishnuvardhana Rao M, Ravinder P, Gal Reddy $\mathrm{C}$, et al. Micronized Ferric Pyrophosphate Supplied through Extruded Rice Kernels Improves Body Iron Stores in Children: a Double-Blind, Randomized, Placebo-Controlled Midday Meal Feeding Trial in Indian School Children 1-3. The American Journal of Clinical Nutrition. 2011;94(5):1202-1210.

16. Grosse SD, Berry RJ, Mick Tilford J, Kucik JE, Waitzman NJ. Retrospective Assessment of Cost Savings from Prevention: Folic Acid Fortification and Spina Bifida in the U.S. American Journal of Preventive Medicine. 2016;50(5):74-80.

17. KooshkiA, Mohammadi M, Rivandi M. Nutritional Intake and its Association with Educational Achievement in High-School Students in Islamic Republic of Iran. Eastern Mediterranean Health Journal. 2018;24(6):532-537.

18. Nilsson TK, Yngve A, Bottiger AK, Hurtig-Wennlof A, Sjostrom M. High Folate Intake sis Related to Better Academic Achievement in Swedish Adolescents. Pediatrics [Online Journal]. 2011;128(2):358-365. Available at: http://www.pediatrics.org/cgi/ doi/10.1542/peds.2010-1481

19. Meeusen R. Exercise, Nutrition and the Brain. Sports Medicine. 2014;44(Supplement 1):2756.

20. Lemeshow S, David WH, pramono D. Besar Sampel Dalam Penelitian Kesehatan. Yogyakarta: Gadjah Mada University Press; 1997.

21. Gregory JF. Case Study: Folate Bioavailability. The Journal of Nutrition. 2001;131(4):1376-1382.

22. JC T, JW N. Folate Status of Adolescents: Effects of Folic Acid Supplementation. Journal of the American Dietetic Association. 1990;90(11):1551-1556.

23. Jani R, Salian N, Udipi S, Ghugre P, Lohia N,
Haas J, et al. Folate Status and Intake of Tribal Indian Adolescents Aged 10 to 17 Years. Food and Nutrition Bulletin. 2015;36(1):1423.

24. Ma F, Wu T, Zhao J, Han F, Marseglia A, Liu H, et al. Effects of 6-Month Folic Acid Supplementation on Cognitive Function and Blood Biomarkers in Mild Cognitive Impairment: A Randomized Controlled Trial in China. The Journals Gerontology Series A. 2016;71(10):1376-1383.

25. Fiedler JL, Afidra R, Mugambi G, Tehinse J, Kabaghe G, Zulu R, et al. Maize flour fortification in Africa: Markets, Feasibility, Coverage, and Costs. Annals of the New York Academy Sciences. 2014;1312(1):26-39.

26. Norris D. Short-Term Memory and LongTerm Memory are Still Different. Psychological Bulletin. 2017;143(9):992-1009.

27. Khodashenas E, Mohammadzadeh A, Sohrabi M, Izanloo A. The Effect of Zinc Supplementation on Cognitive Performance in School Children. International Journal of Pediatrics. 2015;3(6.1):1033-1038.

28. Robinson JG, Farnier $M$, Krempf $M$, Bergeron J, Luc G, Averna M, et al. Efficacy and Safety of Alirocumab in Reducing Lipids and Cardiovascular Events. The New England Journal of Medicine [Online Journal]. 2015;372:1489-1499. Available at: https://www.nejm.org/doi/full/10.1056/NEJMoa1501031

29. Olsen RK, Moses SN, Riggs L, Ryan JD. The Hippocampus Supports Multiple Cognitive Processes Through Relational Binding and Comparison. Frontiers in Human Neuroscience. 2012;6:146.

30. Sen A, Kanani SJ. Impact of Iron-Folic Acid Supplementation on Cognitive Abilities of School Girls in Vadodara. Indian Pediatrics. 2009;46(2):137-143. 